\title{
PENGARUH KEBUTUHAN KOGNISI, PREFERENSI RISIKO DAN JENIS KELAMIN TERHADAP NIAT BERWIRAUSAHA MAHASISWA
}

\author{
Fanny Bidori dan Ida Puspitowati \\ ${ }^{1}$ Program Studi Sarjana Manajemen, Universitas Tarumanagara \\ Email: fannybidorii@gmail.com \\ ${ }^{2}$ Program Studi Sarjana Manajemen, Universitas Tarumanagara \\ Email: idap@fe.untar.ac.id
}

\begin{abstract}
This study aims to empirically examine the effect of cognitive needs, risk preferences and gender on entrepreneurial intentions in private university students in West Jakarta. This research uses data processing method with SmartPLS version 3.0. with a sample of 250 respondents from FE students at several private universities in West Jakarta. Types of samples Non-probability Sampling with Snowball Sampling. The results of this study indicate that: Cognitive Needs and Risk Preferences have a significant effect on Entrepreneurial Intentions in Private Higher Education Students in West Jakarta, while Gender has no significant effect on Entrepreneurial Intentions in Private Higher Education Students in West Jakarta.
\end{abstract}

Keywords: Cognitive Needs, Risk Preferences, Gender, Entrepreneurial Intentions.

\begin{abstract}
Abstrak: Penelitian ini bertujuan untuk menguji secara empiris pengaruh kebutuhan kognisi, preferensi risiko dan jenis kelamin terhadap niat berwirausaha pada mahasiswa perguruan tinggi swasta di Jakarta Barat. Penelitian ini menggunakan metode pengolahan data dengan SmartPLS versi 3.0. dengan jumlah sampel responden sebanyak 250 responden dari Mahasiswa FE pada beberapa Perguruan Tinggi Swasta di Jakarta Barat. Jenis sampel Nonprobability Sampling dengan Snowball Sampling. Hasil penelitian ini menunjukkan bahwa: Kebutuhan Kognisi dan Preferensi Risiko memiliki pengaruh signifikan terhadap Niat Berwirausaha Pada Mahasiswa Perguruan Tinggi Swasta di Jakarta Barat, sementara Jenis Kelamin tidak memiliki pengaruh signifikan terhadap Niat Berwirausaha Pada Mahasiswa Perguruan Tinggi Swasta di Jakarta Barat.
\end{abstract}

Kata Kunci: Kebutuhan Kognisi, Preferensi Risiko, Jenis Kelamin, Niat Berwirausaha

\section{LATAR BELAKANG}

Kemiskinan dan pengangguran merupakan masalah yang sering terjadi di negara berkembang. Indonesia merupakan negara berkembang juga memiliki permasalahan dalam tingkat kemiskinan dan pengangguran. Sampai saat ini meskipun adanya pergantian kepemimpinan di Indonesia, tetapi permasalahan dalam tingkat kemiskinan dan pengangguran tetap berada pada tingkat yang cukup tinggi. 
Dilihat dari keadaan negara saat ini, secara global negara sedang menghadapi masalah Virus Covid-19 yang begitu mengancam negara dengan salah satu faktor yang terkendala yaitu ekonomi negara menurut Menteri Keuangan (Indrawati, 2020). Permasalahan suatu negara karena terdampak Covid-19 membuktikan bahwa tingkat kemiskinan dan pengangguran semakin tinggi terutama di negara berkembang seperti Indonesia. Sebelum terjadinya Covid-19 di Indonesia kemiskinan dan pengangguran sudah tercatat cukup tinggi tingkatannya, ditambah dengan adanya wabah Virus Covid-19 menjadikan tingkat kemiskinan dan pengangguran semakin meningkat dari sebelumnya. Menurut Badan Pusat Statistik (2020) jumlah kemiskinan dan pengangguran di Indonesia telah tembus 6.88 juta orang pada Februari 2020, jumlah tersebut bertambah 60 ribu orang dibandingkan dengan periode yang sama pada tahun 2019. Telah tercatat tingkat kemiskinan dan pengangguran berdasarkan wilayah sebelum Covid-19 pada periode Februari 2020 Banten dengan 8,01 persen, Papua Barat dengan 6,20 persen, Sulawesi Selatan dengan 6,07 persen, Sulawesi Utara dengan 5,57 persen, Jawa Tengah dengan 4,15 persen, Yogyakarta dengan 3,38 persen dan terakhir Bangka Belitung dengan 3,41 persen.

Badan Pusat Statistik mencatat pandemi Covid-19 telah membawa dampak yang luar biasa terhadap 29,12 juta penduduk pada usia kerja, di mana 2,56 juta penduduk telah menjadi pengangguran. Dari jumlah 760 juta penduduk menjadi bukan angkatan kerja, serta 1,77 juta penduduk sementara tidak bekerja, dan paling banyak 24,03 juta penduduk bekerja dengan pengurangan jam kerja. Keberadaan entrepreneurship merupakan solusi terbaik untuk mengatasi masalah perekonomian negara dalam rangka menjadikan sebuah negara menjadi negara maju (Nistorescu, 2011). Apabila seorang mahasiswa mampu untuk menjadi seorang wirausaha, maka hal ini diharapkan akan dapat menurunkan jumlah pengangguran yang ada di Indonesia serta akan menciptakan lapangan pekerjaan yang baru untuk masyarakat yang tidak memiliki pekerjaan. Universitas merupakan salah satu agen yang berperan dalam menumbuhkan entrepreneurial intention, karena dari sinilah para mahasiswa dipersiapkan untuk menjadi seorang entrepreneur yang memang memiliki perceived feasibility dan perceived desirability untuk menjadi seorang entrepreneur (Hisrich dkk., 2008).

Kendala terbesar dalam menumbuhkan jiwa kewirausahaan pada mahasiswa sebagai generasi penerus bangsa yaitu mengubah pola pikirnya menjadi lebih memilih untuk berwirausaha dibandingkan menjadi karyawan di suatu perusahaan (Ramadhani, 2019). Intensi wirausaha merupakan suatu komponen penting seperti yang terjadi pada mahasiswa di Jakarta Barat (Kurniasih, 2013) dimana intensi berwirausaha masih sangat kecil dikarenakan oleh beberapa hal yaitu kurangnya niat mahasiswa yang mau belajar wirausaha, kurangnya kemauan berwirausaha yang dimiliki mahasiswa dan kurangnya dukungan dari lingkungan sekitar untuk berwirausaha.

Menurut data dari Suku Dinas Perindustrian dan Energi (PE) tahun 2019 Jakarta Barat telah memfokuskan program pengembangan kewirausahaan dengan memberikan pelatihan pada masyarakat umum dan juga mahasiswa perguruan tinggi. Sudah 1.847 masyarakat umum dan mahasiswa telah mengikuti pelatihan kewirausahaan. Dalam hal ini pelatihan kewirausahaan bagi mahasiswa sangat penting dan diharapkan mampu menciptakan jiwa-jiwa wirausaha, sehingga mampu mandiri dan menciptakan lapangan kerja yang setiap tahun terus bertambah.

Menurut Baumol dkk. (2007) kewirausahaan adalah kunci untuk sejumlah hasil-hasil sosial yang diinginkan, termasuk pertumbuhan ekonomi, pengangguran yang lebih rendah, dan modernisasi teknologi. Salah satu alternative untuk meningkatkan pertumbuhan ekonomi, memecahkan masalah kemiskinan dan pengangguran di suatu negara yaitu dengan memberdayakan masyarakat lewat wirausaha. Kewirausahaan memiliki peran strategis dalam mendukung pertumbuhan ekonomi di Indonesia dengan menjaring dan membuka lapangan pekerjaan baru bagi masyarakat, meningkatkan jumlah wirausaha yang berkualitas dan memotivasi orang lain yang mau menjadi wirausaha, semakin banyak wirausaha baru yang lahir maka menjadi suatu 
peluang untuk terciptanya lapangan pekerjaan yang tersedia. Berkembangnya kewirausahaan maka akan lahir berbagai inovasi teknologi, produk maupun jasa baru yang dapat menjadi penopang perekonomi Indonesia ditengah penurunan ekonomi karena Virus Covid-19.

Menurut catatan Kementerian Koperasi dan Usaha Kecil Menengah (UKM) di tahun 2019, jumlah wirausaha di Indonesia meningkat dari yang sebelumnya hanya sebesar 1,67 persen menjadi 3,10 persen. Menurut McClelland (2014) suatu negara dapat dikatakan makmur apabila minimal memiliki jumlah wirausaha sebanyak $2 \%$ dari jumlah populasi penduduk. Laporan International Labor Organization (ILO) mencatat jumlah pengangguran terbuka pada tahun 2009 di Indonesia berjumlah 9,6 juta jiwa (7,6\%), dan 10 persen diantaranya adalah sarjana (Nasrun, 2010). Data dari Badan Pusat Statistik Indonesia mendukung pernyataan ILO tersebut yang menunjukkan sebagian dari jumlah pengangguran di Indonesia adalah mereka yang berpendidikan Diploma/Akademi/dan lulusan Perguruan Tinggi (Setiadi, 2008). Perguruan tinggi sebagai lembaga yang menjadi salah satu panutan masyarakat dapat mengusahakan individu untuk mendorong budaya berwirausaha. Perguruan tinggi diharapkan juga mampu menciptakan wirausahawan yang terlatih, sehingga mampu memberi dorongan niat masyarakat khususnya mahasiswa untuk berwirausaha. Menurut Tjahjono dan Ardi (2008) mahasiswa sebagai komponen masyarakat yang terdidik diharapan dapat membuka lapangan kerja dengan menumbuhkan niat berwirausaha.

Zimmerer (2002) menyatakan bahwa salah satu faktor pendorong pertumbuhan kewirausahaan di suatu negara terletak pada peranan universitas melalui penyelenggaraan pendidikan kewirausahaan. Mahasiswa yang menekuni ilmu manajerial khususnya kewirausahaan, diharapkan memiliki jiwa wirausaha yang tinggi, sehingga hal ini akan mampu membuka lapangan kerja yang lebih luas. Dengan adanya kewirausahaan memberikan jalur bagi para pencari kerja untuk kembali memiliki pekerjaan, sehingga para pekerja bisa memiliki pekerjaan yang layak dan bisa membantu memenuhi perekonomian individu. Peran mahasiswa yang diharapkan masyarakat untuk membuka lapangan pekerjaan harus didasarkan pada niat individu itu untuk berwirausaha (Giantari, 2016).

Widayat dan Matuzahroh (2017) niat diasumsikan sebagai prediktor terbaik dari perilaku dan sebagai faktor motivasi yang mempengaruhi perilaku. Intensi atau niat merupakan tindakan yang diarahkan dari timbulnya hubungan antara pertimbangan yang mendalam, keyakinan, dan keinginan dari dalam diri seseorang dengan tindakan tertentu yang akan dilakukan orang tersebut (Wijaya dkk., 2017). Niat atau intensi merupakan dasar individu untuk berwirausaha dengan diimbangi pada keyakinan terhadap dirinya akan berdampak baik bagi terciptanya wirausahawan baru (Hansfel \& Puspitowati, 2020). Peran mahasiswa dalam memulai wirausaha diasumsikan dapat mempunyai niat wirausaha yang baik untuk memulai penciptaan lapangan pekerjaan bagi para pencari kerja. Niat wirausaha dapat menjadi jalur terbaik bagi mahasiswa untuk memulai usaha membantu para pencari kerja, sehingga mahasiswa dapat menjadi jembatan bagi para pencari kerja dengan lapangan pekerjaan baru di Indonesia. Baron (1998) seorang wirausaha akan berpikir dengan cara yang berbeda dalam hal mengambil keputusan. Proses pengambilan keputusan dapat dipengaruhi oleh proses kognitif.

Mullins dkk. (2002) mengemukakan bahwa berbagai mekanisme kognitif dapat dikaitkan dengan pengidentifikasian peluang dan penilaian penciptaan usaha baru. Mekanisme kognitif ini memiliki peran penting untuk menumbuhkan niat wirausaha pada mahasiswa dalam membuka lapangan pekerjaan baru bagi para pencari kerja. Kognitif inilah yang menjadi kebutuhan bagi mahasiswa untuk diterapkan dalam memulai usaha baru. Selain kognitif yang menjadi kebutuhan seorang wirausaha, memiliki preferensi risiko juga menjadi bagian dalam niat memulai usaha bagi mahasiswa untuk mengenal wirausaha sebelum menciptakan usaha baru. 
Dalam penciptaan usaha baru, tentunya akan melibatkan risiko. Pada tahap ini, individu yang memiliki kecenderungan untuk mengambil risiko akan tetap melanjutkan untuk membentuk usaha baru, berbeda dengan orang yang enggan mengambil risiko yang memiliki kemungkinan untuk tidak melanjutkan untuk membuat usaha baru (Shaver \& Scott, 1991). Menurut Hsee dan Weber (1998) pengambilan risiko inilah yang akan menjadi penentu seorang wirausaha untuk memulai usahanya, maka preferensi risiko menjadi bagian dalam penentuan pengambilan keputusan tersebut. Preferensi risiko inilah yang memberikan perbedaan keputusan yang akan diambil oleh seorang wirausaha, bagaimana individu memilih risikonya karena risiko dikaitan dengan masalah kerugian. Mengingat kewirausahaan merupakan aktifitas yang dekat dengan risiko, maka diperlukan keputusan dari preferensi risiko yang akan menjadi penentu bagaimana individu tersebut memilih risiko untuk berwirausaha.

Selain kebutuhan kognisi dan preferensi risiko faktor lain yang bisa menjadi pengaruh terhadap niat wirausaha yaitu jenis kelamin, telah dibuktikan menurut Maes dkk. (2014) peran jenis kelamin telah dihipotesiskan sebagai faktor (mediator) dan diperlakukan sebagai indikator (moderator) yang mempengaruhi niat berwirausaha. Jenis kelamin juga dapat mempengaruhi mahasiswa dalam menciptakan lapangan pekerjaan akankah jenis kelamin pria yang mendominasi terciptanya lapangan kerja baru atau bahkan wanita yang lebih cenderung untuk menciptakan lapangan pekerjaan bagi para pencari kerja.

Tujuan penelitian ini untuk menguji secara empiris pengaruh kebutuhan kognisi, preferensi risiko dan jenis kelamin terhadap niat berwirausaha pada mahasiswa perguruan tinggi swasta di Jakarta Barat.

\section{Rumusan Masalah}

Istilah "Cognitive" berasal dari kata Cognition yang berarti pengertian atau mengerti. Menurut Neisser (1976) kognisi merupakan perolehan, penataan, dan penggunaan pengetahuan. Kebutuhan Kognisi atau NFC (Need for Cognition) adalah kepercayaan seseorang tentang sesuatu yang di dapatkan dari proses berfikir tentang seseorang atau sesuatu. Kapasitas atau kemampuan kognisi biasa diartikan sebagai kecerdasan atau intelegensi. Menurut Wu dkk. (2014) kebutuhan kognisi dapat berinteraksi dengan faktor organisasi dan lingkungan lain untuk mendorong kecenderungan inovasi individu.

Hsee dan Weber (1998) preferensi risiko di definisikan sebagai kecenderungan seorang individu untuk memilih opsi berisiko. Menurut Nyoman (2014) preferensi risiko adalah suatu keadaan dimana individu memilih untuk mengambil risiko atau lebih memilih untuk risiko yang lebih kecil. Risiko dapat diartikan sebagai peluang terjadinya kerugian. Menurut Sitkin dan Pablo (1992) preferensi risiko terdiri dari kecenderungan umum atau keinginan umum, untuk mengejar atau menghindari risiko. Preferensi dipandang sebagai penentu kecenderungan risiko yang didefinisikan sebagai kecenderungan individu untuk mengambil atau menghindari risiko dalam jenis konteks keputusan tertentu (Mullins \& Forlani, 2005; Sitkin \& Pablo, 1992).

Menurut Hungu (2007) jenis kelamin adalah perbedaan antara perempuan dengan laki-laki secara biologis sejak seseorang lahir. Jenis kelamin digunakan untuk menjelaskan perbedaan peran perempuan dan laki-laki yang bersifat bawaan sebagai ciptaan Tuhan. Jenis kelamin adalah pembedaan peran, kedudukan, tanggung jawab, dan pembagian kerja antara laki-laki dan perempuan yang ditetapkan oleh masyarakat berdasarkan sifat perempuan dan laki-laki yang dianggap pantas menurut norma, adat istiadat, kepercayaan atau kebiasaan masyarakat. Menurut Markus dan Kitayama (1991) wanita lebih mendefinisikan diri mereka sendiri dalam kaitannya dengan orang lain daripada pria. Pria juga lebih sering dideskripsikan sebagai otonom dan bertindak independen terhadap orang lain daripada wanita (Williams \& Best, 1982). 
Niat Berwirausaha merupakan kebulatan tekad seseorang untuk menjadi seorang wirausaha atau untuk berwirausaha. Intensi kewirausahaan merupakan kecenderungan seseorang untuk bertindak memulai suatu usaha baru dengan mengimplementasikan ide-ide dan kreativitas pada usahanya (Santoso \& Selamat, 2019). Tubbs dan Ekeberg (1991) menyatakan bahwa niat wirausaha adalah representasi dari tindakan yang direncanakan untuk melakukan perilaku kewirausahaan. Niat kewirausahaan mengacu pada keadaan pikiran bahwa individu ingin membuat perusahaan baru atau pendorong nilai baru di dalam perusahaan yang ada (Nabi dkk., 2006; Guerrero dkk., 2008; Wu, 2012). Y1ldırım dkk. (2016) "Entrepreneurial intention is an individual's state of mind, leading toward the development and the implementation of new business concepts" yang berarti keadaan pikiran individu, yang mengarah pada pengembangan dan penerapan konsep bisnis baru.

\section{Kaitan antara Kebutuhan Kognisi Dengan Niat Berwirausaha}

Menurut Indarti dan Roastiani (2008) kebutuhan kognitif memiliki pengaruh terhadap niat untuk berwirausaha. Menurut Grégoire dkk. (2011) kebutuhan kognisi memiliki pengaruh yang signifikan terhadap pengembangan sikap yang disukai terhadap niat kewirausahaan. Hmieleski et al. (2006) "found that cognitive style significantly impacts entrepreneurial intentions" yang berarti kognitif berdampak signifikan pada niat kewirausahaan. "Cognition and action are central in entrepreneurship research as they hold key to understanding success factors" (Awais \& Manzoor, 2011), kognisi sangat penting dalam kewirausahaan, karena kognisi merupakan faktor kesuksesan.

H1: Terdapat pengaruh signifikan Kebutuhan Kognisi terhadap Niat Berwirausaha.

\section{Kaitan antara Preferensi Risiko Dengan Niat Berwirausaha}

Triawan dan Sumaryono (2008) seseorang dengan kecenderungan risiko tinggi akan memiliki niat berwirausaha yang tinggi karena tidak takut untuk menghadapi risiko. Barbosa et al. (2007) "Our research model proposes a direct relationship between risk perception (risk as opportunity and risk as threat) and entrepreneurial intention as well as an indirect one" yang berarti hubungan langsung antara risiko sebagai peluang dan ancaman dengan niat kewirausahaan. Psikologi risiko atau preferensi risiko inilah yang memprediksi niat kewirausahaan individu (Barbosa dkk., 2007). Dengan demikian, preferensi risiko memiliki pengaruh yang signifikan dengan niat berwirausaha.

Menurut Ozaralli dan Rivenburgh (2016) dalam penelitiannya menjelaskan bahwa terdapat hubungan yang signifikan antara risiko dengan intensi berwirausaha. Risiko sebagai peluang berkaitan dengan gagasan bahwa individu tidak ingin melewatkan kesempatan dan potensi keuntungan terkait dengan demikian mungkin mengalami penyesalan sebelum membuat keputusan untuk terlibat dalam perilaku kewirausahaan.

H2: Terdapat pengaruh signifikan Preferensi Risiko terhadap Niat Berwirausaha.

\section{Kaitan antara Jenis Kelamin Dengan Niat Berwirausaha}

Menurut Sarwoko dan Nurdiana (2013) menunjukkan perbedaan jenis kelamin penting dalam faktor-faktor yang membentuk niat kewirausahaan. Pengaruh gender atau jenis kelamin terhadap intensi seseorang menjadi wirausaha telah banyak diteliti (Mazzarol et al., 1999; Kolvereid, 1996; Matthews \& Moser, 1996; Schiller \& Crewson, 1997). Azhar dkk. (2010) menyatakan bahwa jenis kelamin berkorelasi positif dengan minat berwirausaha. "Several studies related to EI applying the TPB framework have considered gender as a control variable that could affect EI" (Carr \& Sequeira, 2007; Liñán \& Chen, 2009; Yan et al. 2013), TPB menganggap gender sebagai variabel kontrol yang dapat mempengaruhi niat wirausaha. 
Menurut Sarah (2010) mengungkapkan jenis kelamin masih menjadi masalah untuk sebagian wanita dalam membangun sebuah usaha karena wanita diragukan kemampuannya untuk menjalankan usaha sendiri. Menurut Yuhendri (2015) yang meneliti perbedaan minat berwirausaha di kalangan universitas menurut jenis kelamin mendapatkan bahwa terdapat perbedaan antara minat berwirausaha pria dan wanita pada fakultas ekonomi.

Menurut Yunilasari dan Rahardjo (2016) gender tidak berpengaruh terhadap kemampuan dan minat wirausaha mahasiswa. Menurut Syahran dan Rosalina (2020) berwirausaha tidak dipengaruhi oleh gender, baik laki-laki maupun perempuan. Dalam berwirausaha peran jenis kelamin justru hanya menjadi pembeda dalam niat memulai usaha, penelitian ini sejalan dengan penelitian (Orser \& Scott, 2002) beberapa studi empiris yang membandingkan pengusaha lakilaki dan perempuan menunjukkan bahwa perempuan memiliki niat pertumbuhan yang lebih rendah daripada laki-laki.

H3: Terdapat pengaruh signifikan Jenis Kelamin terhadap Niat Berwirausaha.

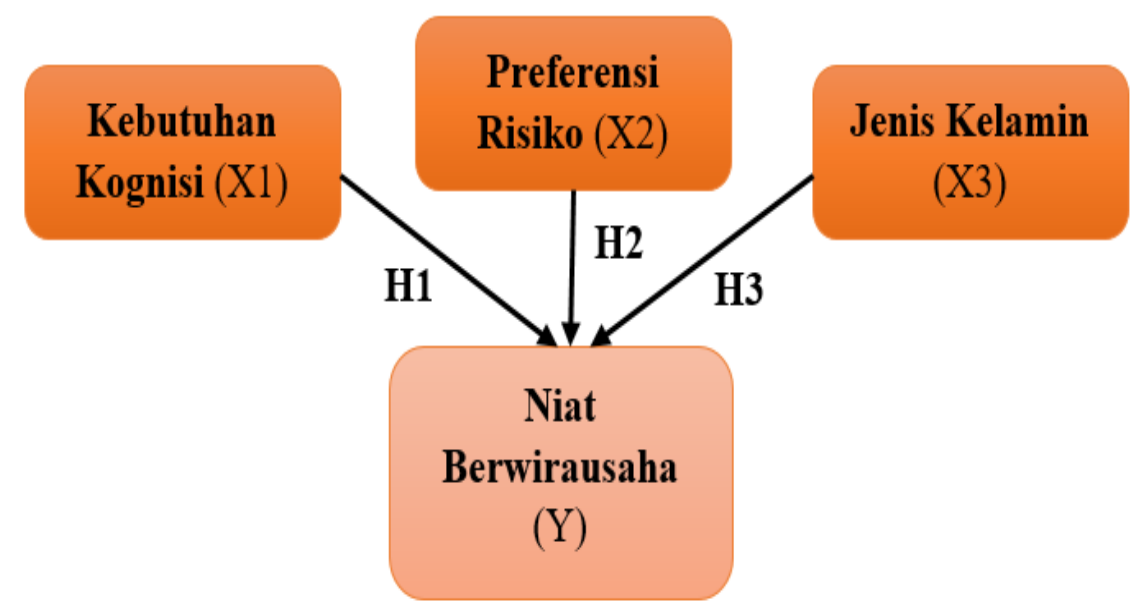

Gambar 1. Model Penelitian

\section{METODE PENELITIAN}

Dalam penelitian ini digunakan metode deskriptif kuantitatif. Dari populasi yang ada, teknik pengambilan sampel yang akan digunakan dalam penelitian ini adalah teknik Nonprobability Sampling. Jenis sampel yang digunakan pada teknik Nonprobability Sampling, yaitu Snowball Sampling merupakan metoda sampling di mana sampel diperoleh melalui proses bergulir dari satu responden ke responden lainnya. Dalam penelitian ini, peneliti tidak banyak mengetahui tentang populasi penelitiannya, sehingga peneliti harus meminta bantuan kepada beberapa responden untuk menyebarkan penelitian ini kepada responden lain. penelitian ini menggunakan jumlah sampel yang akan diambil sebanyak 250 responden yang terdiri dari 50 responden dari 5 perguruan tinggi yang berbeda, sehingga sampel penelitian yang digunakan dalam penelitian ini terdiri dari seluruh mahasiswa dari fakultas FEB Universitas Tarumanagara, FE Universitas Trisakti, FE Universitas Kristen Krida Wacana, FE Universitas Bina Sarana Informatika, dan FEB Universitas Mercu Buana.

Variabel dalam penelitian ini disusun dengan skala likert dengan indikator pengukuran variabel sebagai berikut: 
Tabel 1. Indikator Variabel Penelitian

Sumber: Hooman (2019), Zaidatol, dkk (2013), Francisco (2013), Djumilah, dkk (2012), Made (2016), Natalia dan Rodhiah (2009)

\section{Variabel}

Kebutuhan Kognisi

- Cenderung memilih masalah yang kompleks dari pada masalah sederhana

- Menyukai hidup penuh tantangan yang harus dipecahkan

- Merasa lega setelah menyelesaikan tugas dengan banyak usaha

- Berunding dengan keluarga tentang suatu masalah

- Memahami kekuatan dan kelemahan intelektual

- Memiliki tujuan khusus dari setiap strategi

- Strategi yang paling efektif

- Cenderung mengambil risiko lebih besar

- Bisnis baru adalah sebuah risiko

- Menjalankan bisnis sama dengan mengambil risiko

Preferensi Risiko

Jenis Kelamin

- Jika tidak memulai bisnis akan kehilangan kesempatan besar

- Risiko dari sebuah usaha cukup tinggi

- Peran perempuan menjadi tanggung jawab ekonomi keluarga

- Peran laki-laki menjadi tanggung jawab ekonomi keluarga

- Memulai bisnis adalah ide yang menarik

- Memulai bisnis sendiri dalam waktu tiga tahun ke depan

- Bekerja keras jika memulai bisnis sendiri

- Memilih berwirausaha dari pada bekerja dengan orang

Niat Berwirausaha

- Berkarir sebagai wirausaha

- Melakukan perencanaan suatu usaha

- Melakukan segala upaya untuk menjadi seorang 
wirausha

- Mencari peluang untuk memulai usaha

- Memiliki keraguan serius untuk memulai usaha

Data yang diperoleh dari hasil penelitian diolah menggunakan teknik analisis data dengan Partial Least Square (PLS). Pengolahan data dalam penelitian ini menggunakan software SmartPLS versi 3.0. Dalam PLS-SEM terdapat dua jenis validitas convergent validity dan discriminant validity, Convergent validity dinyatakan valid jika mempunyai loading factors di atas 0,50 terhadap konstruk yang dituju. Discriminant validity dapat diketahui dari nilai pada Fornell-Larcker Criterion yang digunakan untuk meyakinkan validitas diskriminan, maka AVE untuk setiap variabel laten harus lebih tinggi dari $\mathrm{R}^{2}$.

Tabel 2. Uji Validitas dan Reliabilitas

Sumber: Hasil olah data SmartPLS versi 3.0

\begin{tabular}{lcccc}
\hline \multicolumn{1}{c}{ Variabel } & $\begin{array}{c}\text { Fornell- } \\
\text { Larcker } \\
\text { Criterion }\end{array}$ & $\begin{array}{c}\text { Average } \\
\text { Variance } \\
\text { Extracted }\end{array}$ & $\begin{array}{c}\text { Cronbanch' } \\
\text { Alpha }\end{array}$ & $\begin{array}{c}\text { Composite } \\
\text { Reliability }\end{array}$ \\
\hline $\begin{array}{l}\text { Kebutuhan } \\
\text { Kognisi }\end{array}$ & 0,725 & 0,525 & 0,846 & 0,884 \\
\hline $\begin{array}{l}\text { Preferensi } \\
\text { Risiko }\end{array}$ & 0,758 & 0,574 & 0,818 & 0,871 \\
\hline Jenis Kelamin & 0,849 & 0,721 & 0,612 & 0,838 \\
\hline $\begin{array}{l}\text { Niat } \\
\text { Berwirausaha }\end{array}$ & 0,781 & & & 0,933 \\
\hline
\end{tabular}

\section{HASIL DAN PEMBAHASAN}

Berdasarkan hasil nilai pada Adjusted $\mathrm{R}$-square (Adj $\mathrm{R}^{2}$ ) kebutuhan kognisi, preferensi risiko dan jenis kelamin memiliki pengaruh sedang terhadap niat berwirausaha mahasiswa sebesar $43,7 \%$ dan sisanya sebanyak 56,3\% dipengaruhi oleh variabel lain yang tidak terdapat dalam penelitian ini. Selanjutnya pada hasil uji Q-square $\left(\mathrm{Q}^{2}\right)$ menunjukkan kebutuhan kognisi, preferensi risiko dan jenis kelamin memiliki pengaruh kecil bagi niat berwirausaha mahasiswa sebesar 0,264. Adapun nilai pada GoF pada penelitian ini sebesar 0,519 yang menunjukkan bahwa nilai atau tingkat kelayakan pada model penelitian ini dinyatakan besar. 
Tabel 3. Hasil Uji Hipotesis

Sumber: Hasil olah data SmartPLS versi 3.0

\begin{tabular}{|c|c|c|c|c|}
\hline Keterangan & Path Coefficient & t-statistic & p-value & Hasil \\
\hline $\begin{array}{c}\text { Kebutuhan } \\
\text { Kognisi } \rightarrow \text { Niat } \\
\text { Berwirausaha }\end{array}$ & 0,260 & 2,825 & 0,005 & Signifikan \\
\hline $\begin{array}{c}\text { Preferensi } \\
\text { Risiko } \rightarrow \text { Niat } \\
\text { Berwirausaha }\end{array}$ & 0,397 & 4,317 & 0,000 & Signifikan \\
\hline $\begin{array}{c}\text { Jenis Kelamin } \\
\quad \rightarrow \text { Niat } \\
\text { Berwirausaha }\end{array}$ & 0,104 & 1,602 & 0,110 & Tidak Signifikan \\
\hline \multicolumn{5}{|c|}{$\begin{array}{l}\text { Berdasarkan tabel tersebut dapat disimpulkan bahwa variabel kebutuhan kognisi dan preferensi } \\
\text { risiko berpengaruh secara signifikan, dimana masing-masing nilai t-statistic dari setiap variabel } \\
>1,96 \text { dan nilai p-value dari masing-masing variabel }<0,05 \text { tetapi tidak dengan variable jenis } \\
\text { kelamin yang mempunyai nilai t-statistic }<1,96 \text { dan nilai p-value }>0,05 \text { yang berarti jenis } \\
\text { kelamin tidak berpengaruh secara signifikan terhadap niat berwirausaha. }\end{array}$} \\
\hline \multicolumn{5}{|c|}{$\begin{array}{l}\text { Berdasarkan uji hipotesis yang telah dilakukan maka hipotesis } \mathrm{H} 1 \text { : dapat diterima, yang berarti } \\
\text { kebutuhan kognisi memiliki pengaruh signifikan terhadap niat berwirausaha mahasiswa } \\
\text { perguruan tinggi swasta di Jakarta Barat. Hasil penelitian ini sejalan dengan penelitian yang telah } \\
\text { dilakukan sebelumnya oleh Indarti dan Roastiani (2016) bahwa kebutuhan kognitif memiliki } \\
\text { pengaruh terhadap niat untuk berwirausaha. }\end{array}$} \\
\hline \multicolumn{5}{|c|}{$\begin{array}{l}\text { Selanjutnya hipotesis } \mathrm{H} 2 \text { : dapat diterima, yang berarti preferensi risiko memiliki pengaruh } \\
\text { signifikan terhadap niat berwirausaha mahasiswa perguruan tinggi swasta di Jakarta Barat. Hasil } \\
\text { penelitian ini sejalan dengan penelitian yang telah dilakukan sebelumnya oleh Triawan dan } \\
\text { Sumaryono (2008) seseorang dengan kecenderungan risiko tinggi akan memiliki niat } \\
\text { berwirausaha yang tinggi karena tidak takut untuk menghadapi risiko. }\end{array}$} \\
\hline $\begin{array}{l}\text { Untuk hipotesis } \\
\text { seharusnya, bera } \\
\text { mahasiswa perg } \\
\text { yang telah dilak } \\
\text { gender, baik laki } \\
\text { menjadi pembed }\end{array}$ & $\begin{array}{l}\text { : tidak signifika } \\
\text { enis kelamin tida } \\
\text { in tinggi swasta } \\
\text { n oleh Syahran } \\
\text { i maupun perem } \\
\text { lam niat memulai }\end{array}$ & $\begin{array}{l}\text { rena nilai } \\
\text { miliki peng } \\
\text { karta Bara } \\
\text { osalina }(2 \\
\text { dalam ber }\end{array}$ & $\begin{array}{l}\text { value mel } \\
\text { iifikan terl } \\
\text { ian ini se } \\
\text { wirausaha } \\
\text { peran jen }\end{array}$ & $\begin{array}{l}\text { batas nilai yang } \\
\text { niat berwirausaha } \\
\text { dengan penelitian } \\
\text { dipengaruhi oleh } \\
\text { amin justru hanya }\end{array}$ \\
\hline
\end{tabular}

\section{KESIMPULAN}

Berdasarkan hasil penelitian dari bab sebelumnya mengenai pengaruh kebutuhan kognisi, preferensi risiko dan jenis kelamin terhadap niat berwirausaha mahasiswa perguruan tinggi swasta di Jakarta Barat maka dapat disimpulkan kebutuhan kognisi dan preferensi risiko memiliki pengaruh signifikan terhadap niat berwirausaha mahasiswa perguruan tinggi swasta di 
Jakarta Barat. Jenis kelamin tidak memiliki pengaruh signifikan terhadap niat berwirausaha mahasiswa perguruan tinggi swasta di Jakarta Barat.

Bagi peneliti selanjutnya, bahwa faktor kebutuhan kognisi dan preferensi risiko dapat dijadikan acuan untuk memulai suatu usaha serta dapat memberikan pelajaran bagi mahasiswa yang mempunyai niat untuk berwirausaha. Variabel jenis kelamin merupakan variabel yang tidak berpengaruh signifikan terhadap niat berwirausaha sehingga jenis kelamin dapat dijadikan penelitian lebih lanjut.

\section{REFERENSI}

Andika dan Nyoman. (2014). Pengaruh preferensi risiko, etika dan partisipasi penyusunan anggaran pada senjangan anggaran pendapatan di pemerintah provinsi bali. E-Jurnal Ekonomi dan Bisnis Universitas Udayana.

Azhar dan Arsyad. (2010). Media Pembelajaran. Jakarta: PT. Raja Grafindo Persada.

Baumol, W. J., R. E. Litan, dan C. J. Schramm. (2007). Sustaining Entrepreneurial Capitalism. Capitalism and Society, 2(2), 1-38.

Giantari, N. P. (2016). Peran pendidikan kewirausahaan dalam memediasi pengaruh norma subjektif terhadap niat berwirausaha. E-Jurnal Manajemen Unud, 5(1), 533-560.

Hansfel dan Puspitowati. (2020). Pengaruh Attitude, Subjective Norm dan Perceived Behavior Control terhadap Entrepreneurial Intention. Jurnal Manajerial dan Kewirausahaan, 2(4), 985-993.

Hisrich, R.D., Peters, M.P., dan Shepherd D.A. (2008). Kewirausahaan Edisi 7. Edisi Bahasa Indonesia. Jakarta: Salemba Empat.

Hmieleski, K.M. and Corbett, A.C. (2006). Proclivity for improvisation as a predictor of entrepreneurial intentions. Journal of Small Business Management, 44(1), 45-63

Indah Yunilasari, R. (2016). Analsis Pengaruh Faktor Gender Dan Lingkungan Keluarga Terhadap Minat Mahasiswa. Diponegoro Journal Of Management, 5(3), 1-11.

Kurniasih, A., Lestari S.D. dan Herminingsih A. (2013). Persepsi mahasiswa terhadap kuliah kewirausahaan dan pengaruhnya terhadap sikap dan intensi berwirausaha mahasiswa. Jurnal Ilmu Ekonomi dan Sosial, 2 (2), 129-146.

McClelland, D. C. (1961). The Achieving Society, Prin-ceton. NJ: Van Nostrand.

Mullins, J, Walker, O, C, Boyd, H, W and Larreche, J, C. 2005. "Marketing Management: A Strategic Decision - Making Approach”. McGraw - Hill, New York.

Markus, H.R., and Kitayama, S. (1991). Culture and the self: Implications for cognition, emotion, and motivation. Psychological Review, 98, 224-253.

Nasrun, M. A. (2010). Mengapa Banyak Sarjana yang Menganggur, Suara Merdeka.

Neisser, Ulric. (1976). Cognition and reality: Principles and Implication Of Cognitive Psychology. San Francisco: Freeman and Company 
Nistorescu, T. D. (2015). Determinants of Entrepreneurial Intent of Student in Oltenia Region. Review of International Comparative 12 (2).

Nurul Indarti, dan Rokhima Rostiani. (2008). Intensi Kewirausahaan Mahasiswa: Studi perbandingan antara Indonesia, Jepan, dan Norwegia. Jurnal Ekonomika dan Bisnis Indonesia 23(4).

Ozaralli, N., and Rivenburgh, N. K. (2016). Entrepreneurial Intention: Antecedents to Entrepreneurial Behavior in the U.S.A. and Turkey. Journal of Global Entrepreneurship Research, 6(3), 1-32.

Rodhiah, C. N. (2019). Pengaruh Kreativitas, Edukasi Dan Efikasi Diri Terhadap Intensi Berwirausaha Dalam Generasi Z. Jurnal Manajerial dan Kewirausahaan, 1(2), 164-171.

Santoso dan Slamet. (2019). Pengaruh Dukungan Universitas Dan Sikap Proaktif Terhadap Intensi Kewirausahaan Mahasiswa Di Jakarta. Jurnal Manajerial dan Kewirausahaan, 1(3), 401-410.

Sarwoko E dan Nurdiana I. (2013). "Gender Differences in Entrepreneurial Intentions." International Conference on Entrepreneurship and Business Management, page 91-95.

Setiadi, U. (2008). Suatu Pemikiran Mengenai Pen-dekatan Kembali Antara Dunia Pendidikan S1 Manajemen Dengan Dunia Kerja. Prosiding Konferensi Merefleksi Domain Pendidikan Ekonomi dan Bisnis, Salatiga.

Shaver, K. G. and L. R. Scott. (1991). Person Process, Choice: The Psycology of New Venture Creation." Entrepreneurship Theory and Practice, 16(2): 23-45

Tjahjono, H. K., dan Ardi, H. (2008). Kajian Niat Mahasiswa Manajemen Universitas Muhammadiyah Yogjakarta Untuk Menjadi Wirausaha. Utilitas Jurnal Manajemen dan Bisnis, 16 (1).

Triawan dan Sumaryono. (2008). Kecenderungan Perilaku Pengambilan Resiko Dengan Minat Wirausaha. Psikologika, 26 (13).

Tubbs, M.E. and Ekeberg, S. E. (1991). "The Role of intentions in work motivation: Implications for goal setting theory and research". Academy of Management Review. Vol. 16.

Weber, E. U. and Hsee, C. (1998). Cross-Cultural Differences in Risk Perception, But CrossCultural Similarities in Attitudes towards Perceived Risk. Management Science, 44(9), 1205-1217

Widayat dan Ni'matuzahroh (2017) Entrepreneurial attitude and student business start-up intention: A partial least square modelling. Jurnal Manajemen dan Kewirausahaan, 19(1). 46-53.

Yildirim, C., Sumuer, E., Adnan, M and Yildirim, S. (2016). A Growing Fear: Prevalence of Nomophobia among Turkish College Students. Information Development, 32(5), 13221331

Yuhendri. (2015). Perbedaan Minat Berwirausaha Mahasiswa Ditinjau Dari Jenis Kelamin Dan Pekerjaan Orang Tua. Seminar Nasional Ekonomi Manajemen dan Akuntansi, ISBN: 978602-17129-5-5. 
Zaidatol Akmaliah Lope Pihie, A. B. (2013). Knowledge of cognition and entrepreneurial intentions: Implications for learning entrepreneurship in public and private universities. Social and Behavioral Sciences 97, 174-181.

Zimmerer, W.T. 2002. Essentials of Entrepreneurship and Small Business Management. Third Edition. New York: Prentice-Hall. 